\title{
The Energy Consumption of Terraces in the Barcelona Public Space: Heating the Street
}

\author{
Carlos Alonso-Montolio *(D), Gloria Serra-Coch, Antonio Isalgue (D) and Helena Coch \\ Architecture \& Energy, School of Architecture of Barcelona, Universitat Politècnica de Catalunya, 08034 Barcelona, Spain; \\ gloriaserracoch@gmail.com (G.S.-C.); antonio.isalgue@upc.edu (A.I.); helena.coch@upc.edu (H.C.) \\ * Correspondence: carlos.alonso-montolio@upc.edu; Tel.: +34-934-010-866
}

Citation: Alonso-Montolio, C.; Serra-Coch, G.; Isalgue, A.; Coch, H. The Energy Consumption of Terraces in the Barcelona Public Space:

Heating the Street. Sustainability 2021, 13, 865. https://doi.org/10.3390/ su13020865

Received: 25 November 2020

Accepted: 13 January 2021

Published: 16 January 2021

Publisher's Note: MDPI stays neutral with regard to jurisdictional claims in published maps and institutional affiliations.

Copyright: (c) 2021 by the authors. Licensee MDPI, Basel, Switzerland. This article is an open access article distributed under the terms and conditions of the Creative Commons Attribution (CC BY) license (https:/ / creativecommons.org/licenses/by/ $4.0 /)$.

\begin{abstract}
Terraces, as outdoor extensions of food and beverage businesses located in the public realm, have very high potential to activate the streetscape, bring people together and improving urban experiences. Among the consequences of the current COVID-19 pandemic are the recommendations of maximizing outdoor environments when conducting human interactions. Therefore, outdoor eating has dramatically increased throughout the world, with terraces becoming a radical urban change in many streetscapes. The urgency of the situation, and rapid implementation of these changes, has revealed some aspects of this phenomenon that should be considered when adapting the regulations to this new reality. However, the research on their functioning and impact is limited. Additionally, although energy consumption in the architectural and urban field is considered fundamental, research has rarely addressed small business outdoor spaces, placing the focus instead on residential heating or public lighting. This study focuses on the intersection of these two gaps by analyzing a set of terraces in Barcelona and estimating the power installed in their outdoor heating devices. The goal is to determine the potential energy consumed, contrast it with other values more commonly used when researching architectural energy consumption and point out the lack of sustainability of these approaches to providing comfort. The calculations show that the installed power in Barcelona terraces is significant and, when estimating potential consumption, it presents values higher that the average heating consumption of residential units in Spain. These results support two main conclusions: first, the relevance of addressing the means of providing comfort in outdoor urban spaces due to the high magnitude of their potential energy consumption; second, the importance of adapting those systems to outdoor conditions, understanding the needs of the occupants and the limitations of the environment in order to develop sustainable solutions that provide comfort without attempting to heat the air of the street.
\end{abstract}

Keywords: public space; energy consumption; urban terraces; COVID-19 pandemic

\section{Introduction. Terraces and Public Space. The Case of Barcelona}

There is a type of phenomenon in the urban public space that, although often disregarded by urban planning professionals, is placed at the core of current political and social discussions. Terraces located in the public realm have the potential of highly influencing the dynamics and performance of cities and, therefore, are in need of further analysis and study.

The term "terrace" is generally used to describe architectural outdoor extensions of indoor spaces. For instance, private terraces in residential buildings extend the living area outdoors. In this article, we will focus on a particular case, using the word "terrace" to define the outdoor extension of food and beverage businesses, generally restaurants and cafes (Figure 1). Specifically, we focus on those that make use of the public space to provide this extension [1]. 


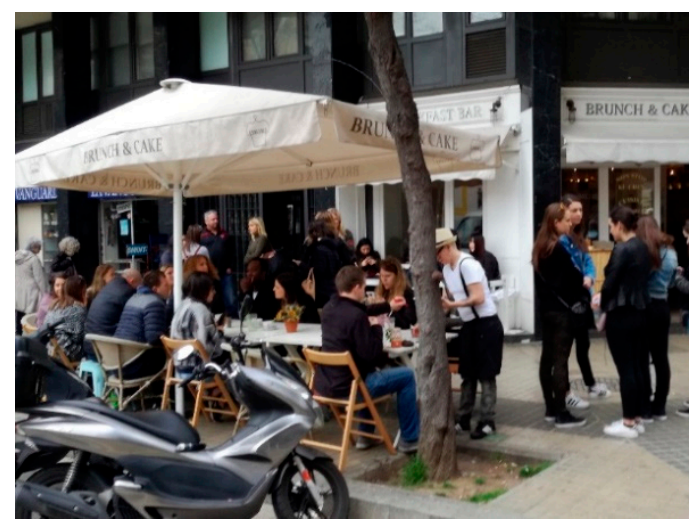

Figure 1. Terrace in Enrique Granados Street, Barcelona.

Our society is currently facing an extraordinary challenge in the form of the COVID-19 pandemic first identified in December 2019 and declared a pandemic in March 2020 by The World Health Organization [2]. It has abruptly disrupted the way of living across the entire world. The events that we are experiencing demand a revision of practices and priorities in our everyday life. A wide range of fields and disciplines will have to adapt and re-think the status quo, urban planning being one of the most significant [3].

Terraces can become key elements in this reflection for two main reasons. First, current quarantine and stay at home situations have revealed the importance of access to outdoor space for the well-being of humans. Sun and open air have been unmasked not only as privileges for the few but as needs for general health and wellness. Secondly, the new standards that will need to be put in place moving forward will demand inventive solutions. Larger spaces will be needed to accommodate the same amount of people and fulfill minimum distance requirements. Terraces could be important to be able to provide outdoor experiences and social interaction with safer distances. Around the world, municipalities are already tackling the challenge, rapidly updating and adapting regulations to the new situation.

There are multiple conditions that allow the existence of this type of terrace. The most basic ones are the presence of food and beverage businesses, the social acceptance to eat in public and the existence of the concept of public space [4].

Traditionally, terraces offered the opportunity of taking advantage of better outdoor conditions, related to thermal comfort, a sunny or airy environment, easier social interaction or better views [5,6]. However, these characteristics are often lost in the current situation. When the urban environment is not considered as positive as desired, elements tend to be incorporated into the terrace in order to protect the client from the outdoor public surroundings (Figure 2). These elements can have different aims, such as protection from the sun (sunshade/parasol), from the car noise and emissions or wind (lateral divisions) or from the cold (heating). In this article, the heating elements incorporated in terraces are the focus of the investigation.

The high level of energy consumption that human activity is currently responsible for is a pressing issue at multiple levels. The scarcity of fossil energy sources, the emissions produced by current energy generation systems, radioactivity pollution from nuclear sources, rise of global temperatures and climate change, lack of basic energy needs of vulnerable populations and limited resiliency in emergency situations.

Cities, suburbs and other urban centers have been identified as a major focus of energy consumption, and great efforts have been devoted to reducing its use. Research, studies and policies $[7,8]$ have attempted to address the issue through a wide range of actions, from reducing private transportation to incentivizing the implementation of renewable energy sources $[9,10]$. 


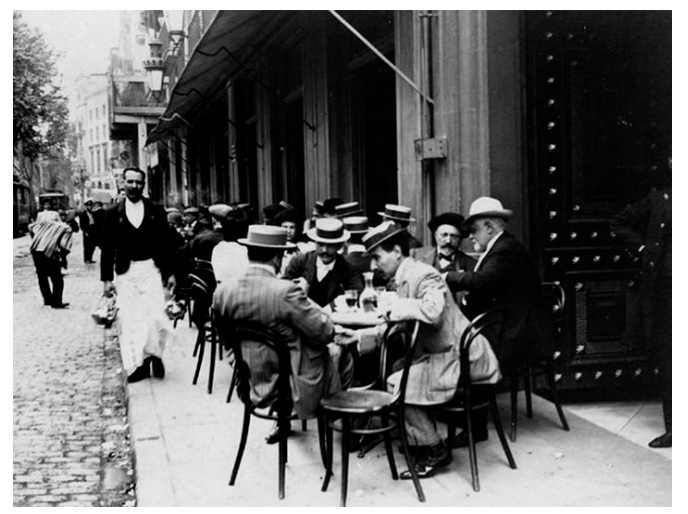

(a)

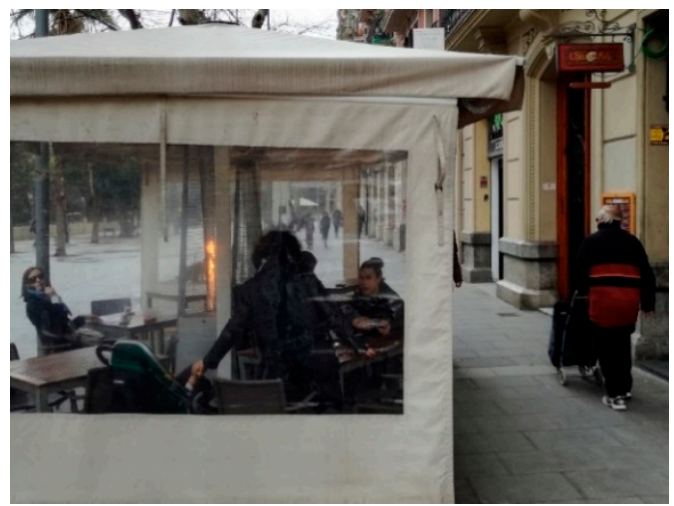

(b)

Figure 2. (a) Hotel Oriente's terrace on Rambla dels Caputxins. Photography by Jesus Fraiz Ordóñez. Barcelona, 1907-1908; (b) terrace in Enrique Granados Street during winter.

In addition, recent economic crises have magnified serious existing issues related to energy poverty. These events have raised sustainability awareness [11] and encouraged a drive for energy saving and an interest in energy efficiency rehabilitation for buildings [12,13]. Studies have shown how the largest energy consumption share within a household is that caused by heating and cooling systems [14,15].

Consequently, significant efforts, both in academia and professional practice, have been focused on the development of strategies that tackle the building environment [16-18]. Through multiple studies, heating and cooling have been identified as an important fraction of energy consumption, especially in residential buildings, and design strategies and policies have been focused on addressing this issue $[19,20]$. Open public space approaches have been generally focused on the management of public lighting or the limiting of certain transportation means [21]. These measures have been established by governmental agencies that have the tools to control these elements of the public realm.

However, other important energy consuming activities are often overlooked. The energy used to light, heat or cool outdoor terraces is rarely accounted for in academic energy studies or governmental policies. This situation might be the consequence of three main factors: first, the difficulty to acquire data on energy consumption from all the disaggregated businesses of a city in comparison with municipal infrastructure; second, the challenges of separating the indoor and outdoor energy consumption of food and beverage businesses; finally, the variability regarding both the presence and heating use of terraces, which are constantly changing due to business closures and openings, opening hours and occupancy, which create difficulties in developing a comprehensive database. Based on the increasing presence of terrasses, a thorough analysis of their energy performance could be key for urban sustainability.

In Barcelona, the number of terraces located in the public space has recently increased very rapidly, under the influence of multiple factors: mild climate, tourism growth, the implementation of the anti-tobacco law [22], widening of sidewalks, prioritization of the pedestrian realm in the public space $[23,24]$, rise of rental prices and the number of foodrelated businesses and, more recently, COVID-19 restrictions. This increment has caused a climate filled with discussions and even conflicts regarding this issue.

This situation has pushed municipal authorities to commission studies [25] that could support the drafting and proposal of new regulations that might address the abovementioned challenges [26-28]. Nevertheless, these studies or regulations fail to address the energy consumption that these elements can potentially cause.

The presence of switched-on heating systems in terraces during the daytime in a city with a Mediterranean climate such as Barcelona, where the average annual temperature is around $18.4^{\circ} \mathrm{C}$ (average temperature of years 2014-18) and with temperatures between 12.4 and $6.1{ }^{\circ} \mathrm{C}$ for the coolest month, February, is questionable (Table 1). 
Table 1. Temperatures in 2014-2018 of Can Bruixa Observatory in the city center of Barcelona, according to the National Meteorology Agency.

\begin{tabular}{cccccc}
\hline $\begin{array}{c}\text { Year/ } \\
\text { Month }\end{array}$ & $\begin{array}{c}\text { Average } \\
\text { Temperature }\end{array}{ }^{\circ} \mathbf{C}$ & $\begin{array}{c}\text { Average Maximum } \\
\text { Temperature }{ }^{\circ} \mathbf{C}\end{array}$ & $\begin{array}{c}\text { Average Minimum } \\
\text { Temperature }{ }^{\circ} \mathbf{C}\end{array}$ & $\begin{array}{c}\text { Extreme Maximum } \\
\text { Temperature }{ }^{\circ} \mathbf{C}\end{array}$ & $\begin{array}{c}\text { Extreme Minimum } \\
\text { Temperature }{ }^{\circ} \mathbf{C}\end{array}$ \\
\hline 2014 & 18.3 & 21.3 & 15.4 & 33.0 & 5.0 \\
2015 & 18.4 & 21.5 & 15.4 & 34.7 & 2.1 \\
2016 & 18.4 & 21.4 & 15.4 & 32.6 & 3.9 \\
2017 & 18.4 & 21.5 & 15.3 & 34.2 & 1.6 \\
\hline 2018 & 18.5 & 21.5 & 15.5 & 22.3 & 0.9 \\
January & 13.3 & 16.3 & 10.2 & 17.4 & 5.7 \\
February & 9.3 & 12.4 & 6.1 & 21.2 & 0.9 \\
March & 13.4 & 17.0 & 9.7 & 24.5 & 3.2 \\
April & 16.7 & 19.7 & 13.7 & 24.9 & 8.5 \\
May & 19.1 & 22.2 & 16.0 & 30.4 & 9.3 \\
June & 23.4 & 26.2 & 20.6 & 32.6 & 16.5 \\
July & 26.7 & 29.6 & 23.8 & 37.8 & 21.0 \\
August & 27.4 & 30.3 & 24.5 & 30.9 & 20.2 \\
September & 24.4 & 27.0 & 21.7 & 25.8 & 7.6 \\
October & 19.6 & 22.7 & 16.4 & 22.3 & 8.9 \\
November & 15.2 & 17.9 & 12.5 & 20.9 & 6.6 \\
December & 13.6 & 16.6 & 10.6 & & \\
\hline
\end{tabular}

\section{Analysis of the Terraces in Barcelona}

Although terraces located in public space seem central in the development of the city, literature addressing this subject is scarce. Terraces are mentioned in certain urbanism publications about public space, but they appear only briefly and often are not directly mentioned. It seems that public space professionals, probably due to their private commercial character, have overlooked this phenomenon. However, terraces have a high impact on morphological and social attributes of the public space. On one hand, they occupy a large amount of pedestrian areas and modify their routes. On the other hand, they offer a meeting point for citizens, contributing a secure and convivial feeling to the neighborhood.

\subsection{Selection of the Zones of Analysis}

In order to proceed with a further analysis of several terrace areas in Barcelona, the first step was conducting a selection of the most significant zones. This choice was based on a cartographic databased work developed by the Centre de Política del Sol i Valoracions (CPSV) and published in "Estudi de caracterització i avaluació de Terrasses en espai public" [25]. From this database, with the use of a Geographic Information System software, 6 zones with the greatest terrace concentrations and diverse urban morphology typologies were detected (Figure 3). The objective was to be able to collect data from areas of the city with a significant presence of this phenomenon and common or diverse characteristics that present a contrasting panorama.

The selected zones:

(a) Enrique Granados Street;

(b) Rambla del Poble Nou;

(c) Plaça Reial and Les Rambles;

(d) Mercat del Born;

(e) Gaudí Avenue;

(f) Paral-lel Avenue and Blai Street.

The terraces studied have different occupancy patterns between office hours and after hours and/or weekends. Two of these areas are located in the urban fabric of the Eixample, but with a substantial difference. Enrique Granados St. (1) is located in an office building area, and during breakfast and midday it is busy with office workers and some tourists, whereas Gaudí Avenue (5), due to being close to Sagrada Familia, has a much higher flow 
of tourists. The two zones in the city center ( 3 and 4 ) are occupied by tourists but have fairly different urban attributes. Plaça Reial (3) has terraces of a larger size and with more equipment than those in Mercat del Born (4), while both have an intense nighttime use. The former ones are restaurants, and their customer stays are longer, while the latter ones in Born (4), an after-hour drinks spot, have shorter customer stays. Rambla del Poble Nou (2) is located around Villa Olimpica, close to the sea, and it is the area that displays the most important difference in occupation between daytime, with a large proportion of locals, and nighttime, with a large proportion of tourists. Blai Street (6) is a narrow pedestrian street close to the entertainment business area Paral-lel, and has its largest flow of people during the nighttime, with both locals and tourists.

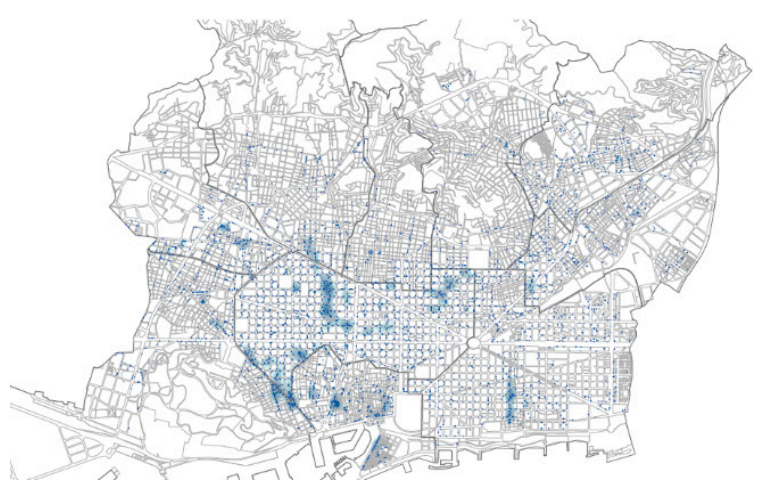

(a)

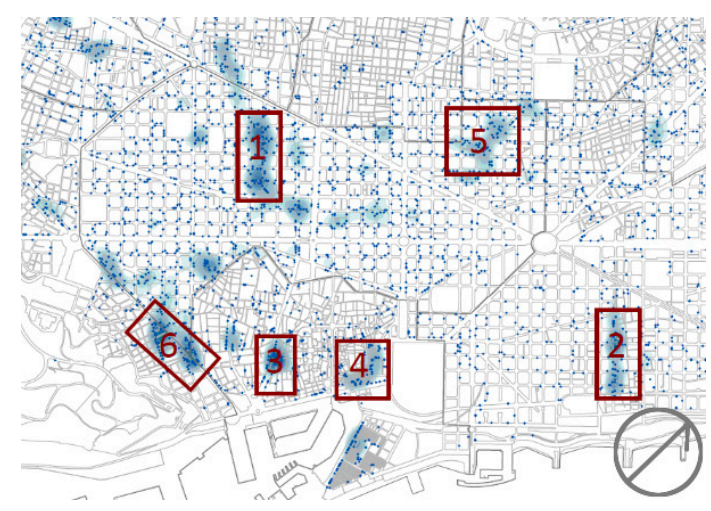

(b)

Figure 3. (a) Map of Barcelona's restaurant business activity [25]; (b) indication of the analyzed zones.

\section{(a) Enrique Granados Street}

Located in the district of central Eixample, Enrique Granados is an example of a vertical axis in the Barcelona grid, with a NW-SE orientation. It connects la Diagonal with Gran Via, two major metropolitan Barcelona avenues. The street has a constant width of $20 \mathrm{~m}$, like all regular streets of l'Eixample grid, but with different section configurations. Although some parts of the street are pedestrianized, the most common section holds $50 \%$ of the surface dedicated to pedestrians, organized in two wide lateral walkways, one direction car lane, a two-way bike lane and a central parking area, which alternates bicycles, motorcycles and cars (Figure 4).
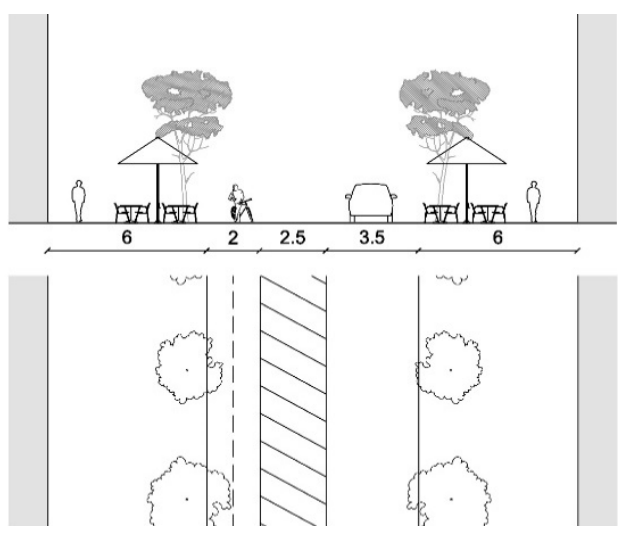

(a)

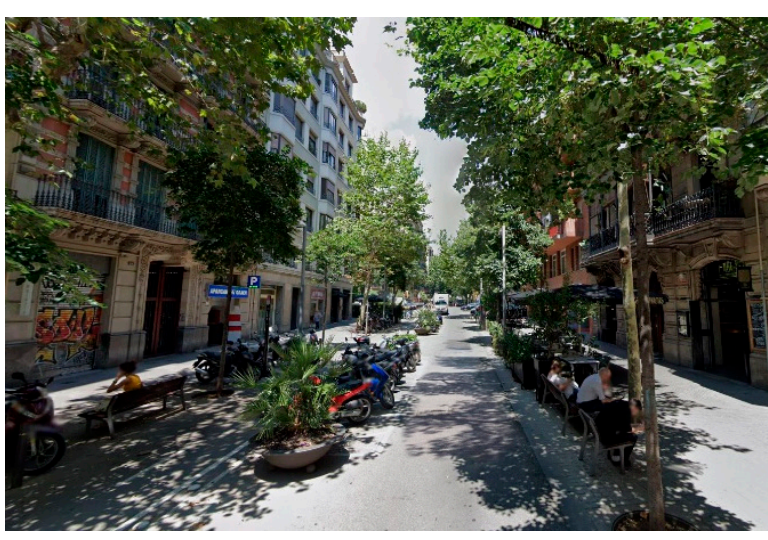

(b)

Figure 4. (a) Plan and section of Enrique Granados Street; (b) street view of Enrique Granados Street. 


\section{(b) Rambla del Poble Nou}

This boulevard is also located in the district of Eixample. It has a width of $30 \mathrm{~m}$ from Avinguda Diagonal to Carrer de Pere IV, and a width of $20 \mathrm{~m}$ for the most part of its length, between Carrer de Pere IV to Passeig de Clavell, with $70 \%$ of the total surface used for pedestrian movement, consisting of lateral walkways smaller than Enrique Granados and a central Rambla that acts as the pedestrian core of the street. It has two car lanes, marked as bicycle priority lanes, split by the Rambla with opposite directions. The width of the lateral sidewalks slightly changes along the street, but the structural elements of the section remain the same (Figures 5 and 6).

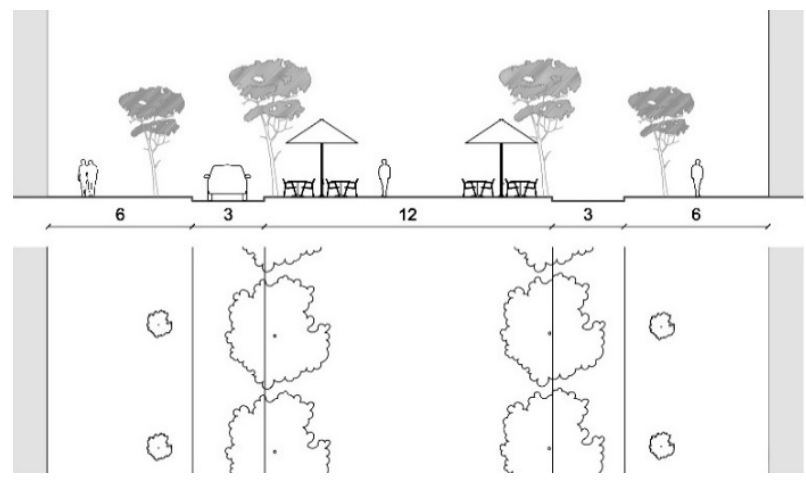

(a)

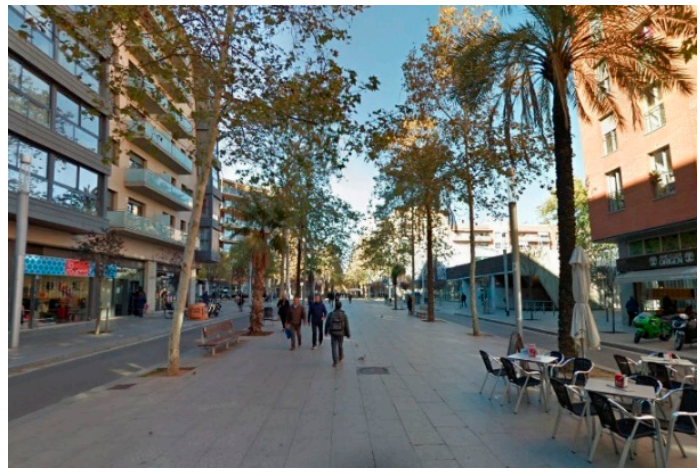

(b)

Figure 5. (a) Plan and section of Rambla del Poble Nou, upper section; (b) street view of Rambla del Poble Nou, upper section.

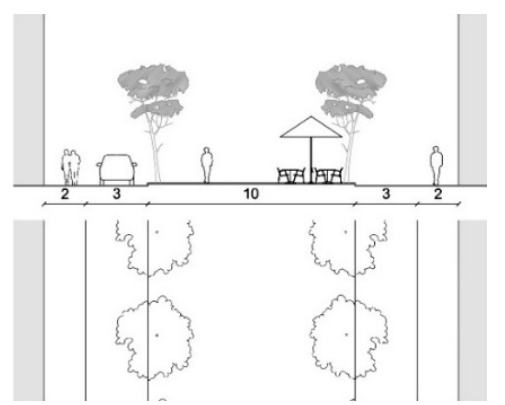

(a)

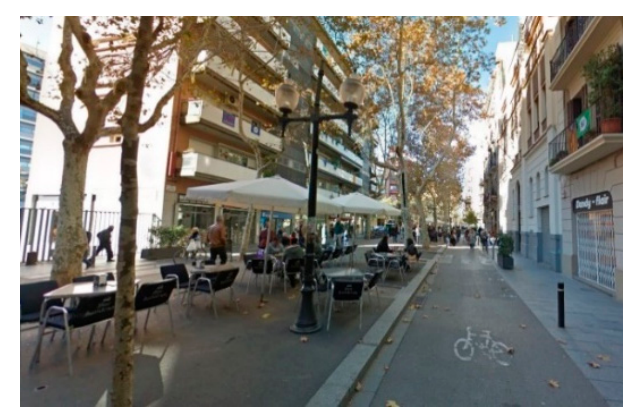

(b)

Figure 6. (a) Plan and section of Rambla del Poble Nou, lower section; (b) street view of Rambla del Poble Nou, lower section.

\section{(c) Plaça Reial and les Rambles}

Plaça Reial is an important square in Barcelona located in the core of the medieval city, tangential to Les Rambles. Measuring $113 \times 75$ m, Plaça Reial presents the first regularized façades of the medieval city through arcades on the ground floor. It has several connections with lateral streets, the most important being Carrer Ferran, the first straight street of the city, and les Rambles. The zone studied in this case also includes several terraces located in Les Rambles. This avenue of Barcelona connects Plaça Catalunya with the sea. It was also formerly the limit between the walled city and the Raval neighborhood, the hors-murailles western extension, now the avenue that divides both neighborhoods and the most touristic axis in Barcelona (Figure 7). 

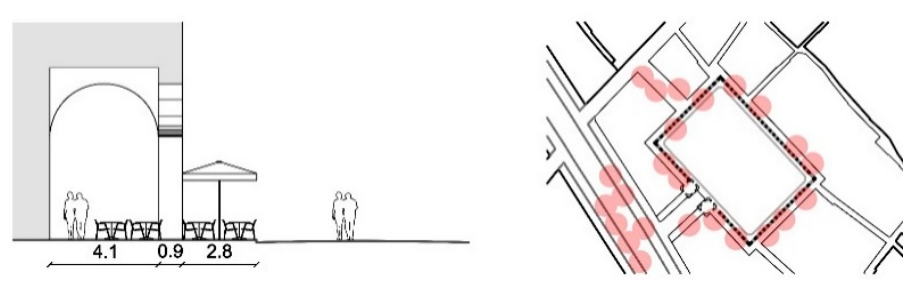

(a)

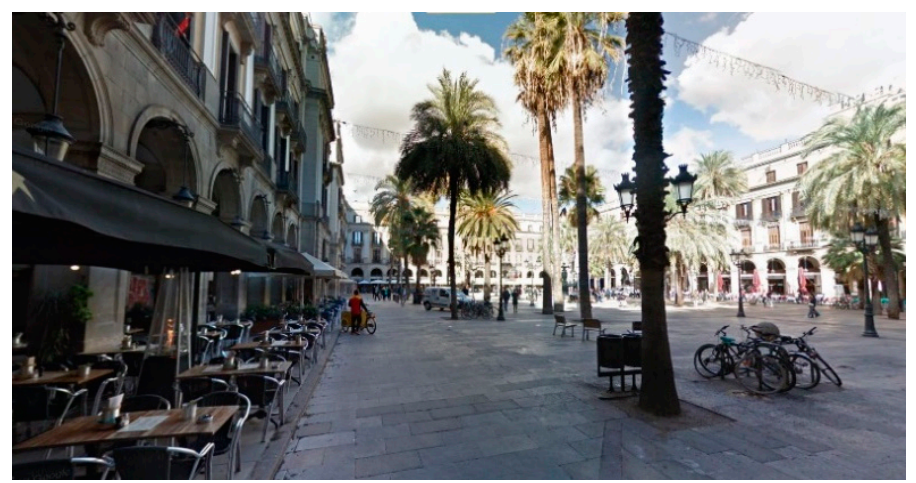

(b)

Figure 7. (a) Plan and section of Plaça Reial; (b) street view of Plaça Reial.

\section{(d) Mercat del Born}

Pedestrian area Mercat del Born is a former municipal market of Barcelona inaugurated in 1876 and located at the end of Passeig del Born. Since September 2013, it has been used as a cultural center accommodating various archaeological remains. The remodeling of the center was complemented by an urban plan that pedestrianized the surrounding area. The $30 \times 70 \mathrm{~m}$ square located at its front, the $20 \mathrm{~m}$ wide Passeig del Born, along with the transformation of the neighborhood, have helped create a leisure area commonly visited by tourists and locals and stimulate the emergence of restaurant businesses (Figure 8).
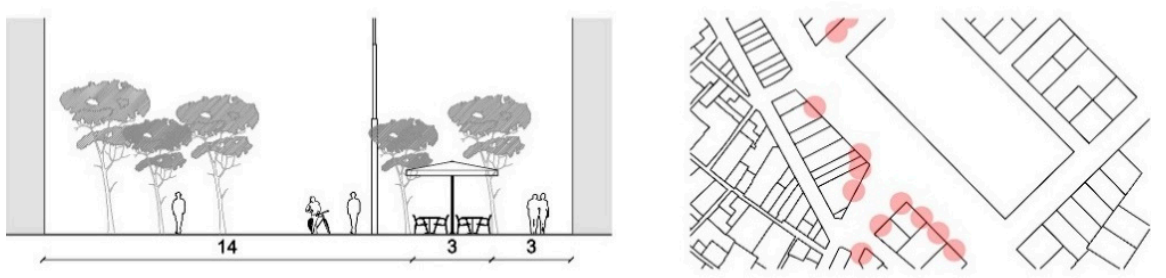

(a)

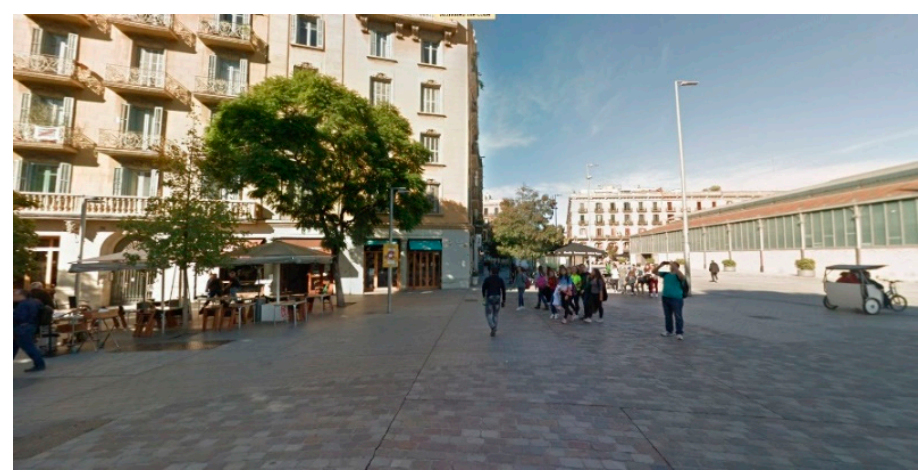

(b)

Figure 8. (a) Plan and section of Mercat del Born area; (b) street view of Mercat del Born area. 


\section{(e) Gaudi Avenue}

Gaudí Avenue is a $25 \mathrm{~m}$ wide street splitting the orthogonal grid of Eixample in a precise north-south diagonal that connects two landmarks, the Sagrada Familia and Hospital de Sant Pau. Originally, it was used as an important driveway, but in 1985, the avenue was remodeled, becoming more pedestrian friendly. Since then, the street has hosted a large number of restaurant businesses frequented by visitors to the Sagrada Familia. Its current layout has two car lanes separated by a $10 \mathrm{~m}$ wide pedestrian way and two other $4 \mathrm{~m}$ wide pedestrian ways adjacent to the building façades, resulting in a $75 \%$ of the section dedicated to pedestrians (Figure 9).

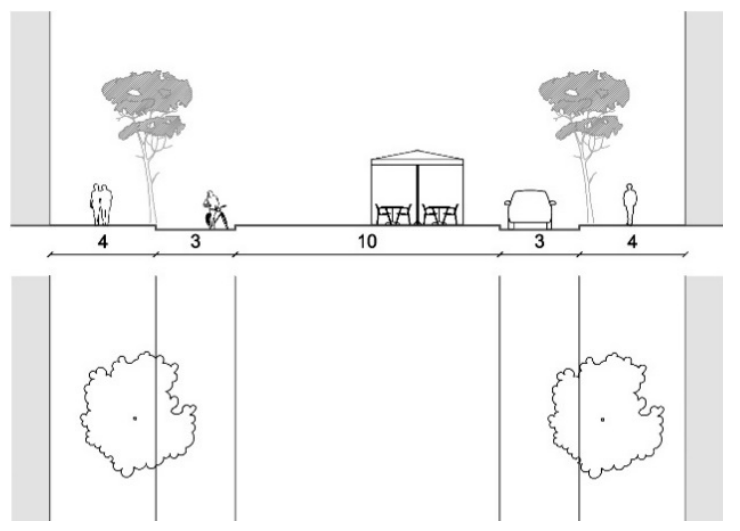

(a)

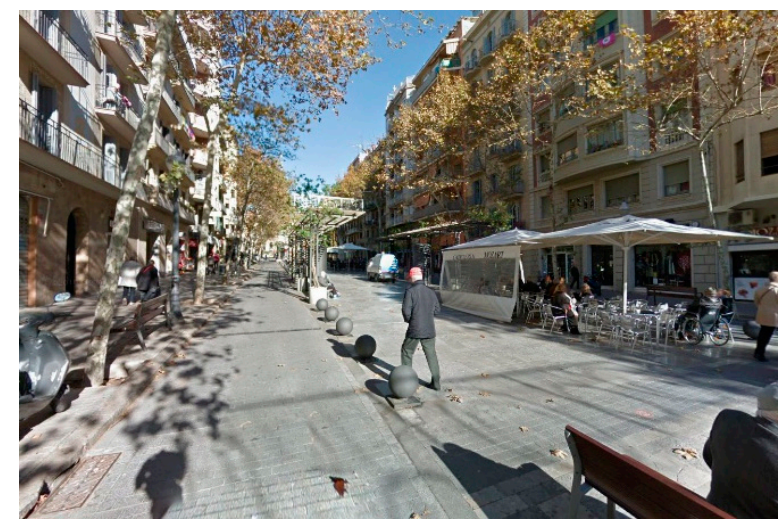

(b)

Figure 9. (a) Plan and section of Gaudí Avenue; (b) street view of Gaudí Avenue.

(f) Paral-lel Avenue and Blai Street. Traffic Focused Street (Paral-lel) vs. Pedestrian Street (Blai)

Paral-lel Avenue is a $40 \mathrm{~m}$ wide street originated after the approval of Pla Cerdà in 1859 that connects Plaça Espanya to the old royal shipyards by the port. It also delimits the boroughs of Poble Sec and Raval. Its trace, following the same east-west direction as the geographic parallel, was established over the demolished medieval city walls. The avenue constituted a leisure axis, especially nightlife businesses, from the last years of the 19th century until the 1970s. Nowadays, it still holds a good number of entertainment businesses, such as theatres, cinemas, concert halls. Its layout gives a total of $40 \%$ of its width to pedestrian areas, arranged in two lateral walkways, two three-lane driveways and a central two-way bicycle lane.

Blai Street is a $450 \mathrm{~m}$ long, $10 \mathrm{~m}$ wide street in the neighborhood of Poble Sec that has recently become very popular. Once unnoticed, this street, aided by its pedestrianization and a rebranding strategy, has become the center of the neighborhood life, filled with bars and terraces (Figures 10 and 11).

\subsection{Data Collection of the Characteristic Elements of the Terraces}

The second step of the process was the creation of a database that assembled the characteristics of the studied terraces.

Each spreadsheet includes 21 attributes organized in three sections: premises data, terrace elements and urban environment. It also contains graphical information: plan and section, an image of the terrace and an environment conceptual diagram describing the relationship with the surroundings (Figure 12).

The first section, premises data, addresses the eight following fields: name and address, date and hour of observation, type of business, price of coffee, price of beer $(33 \mathrm{cl})$, opening schedule and approximate tourist/local client percentage. The price of coffee and beer are used as proxies of the business economic level, as they tend to be sold at all types of terraces, be it restaurants, bars or cafes. Every zone is codified with an ID, from 1 to 6 , and 
every terrace has a number of two digits preceded by the ID of its zone (total of 3 digits) (Figure 13).

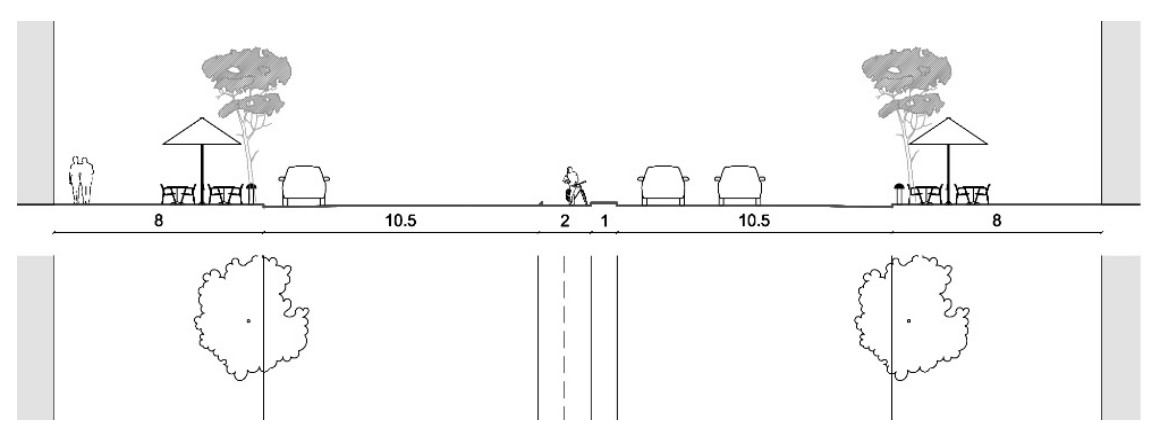

(a)

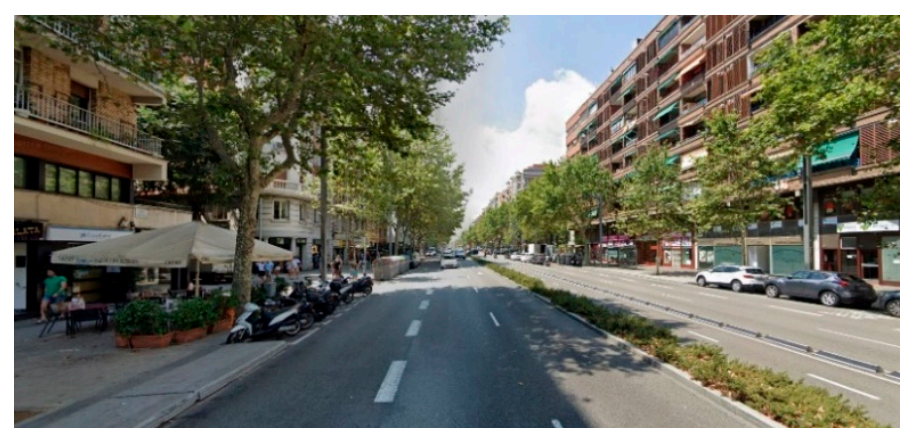

(b)

Figure 10. (a) Plan and section of Paral-lel Avenue; (b) street view of Paral-lel Avenue.

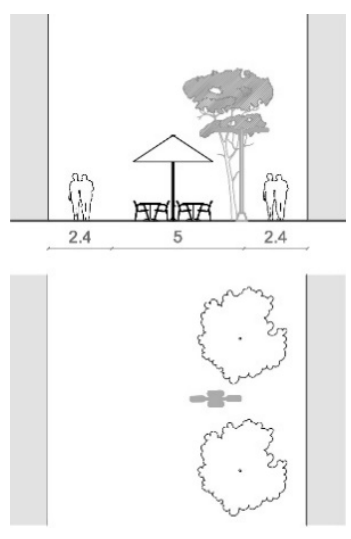

(a)

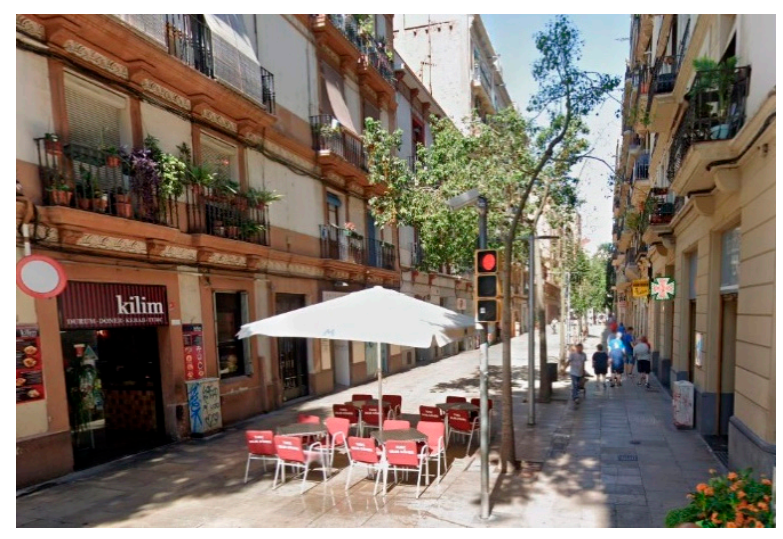

(b)

Figure 11. (a) Plan and section of Blai Street; (b) street view of Blai Street.

The second section, terrace elements, describes the equipment of the terrace. This section is divided into four subsections: seats, tables, auxiliary elements and heating devices (Figure 14). The seats subsection has three fields: number of seats, number of people occupying these seats and the type of chair. The tables subsection includes two fields: number of tables and use or not of tablecloth (the presence of the meal). The last subsection describes the terrace through their auxiliary elements, in addition to tables and chairs, such as umbrellas, planters, awning, platform, buffet, heating and artificial lighting. With the aim of synthesizing the diversity of terraces regarding equipment, eight modules of terrace are defined, based on the previous work by Pia Giannoni [29]. The description of these modules ranges from a terrace with only tables and seats [M1] to a terrace that becomes a physical extension of its own indoor business [M8]. The last subsection, the 
heating subsection, is the one that acts as the basis for the analysis of this research. This part seeks to quantify the heating devices installed for every terrace. It contains 3 fields: gas, electric and interior, which describe the type and number of heating devices.

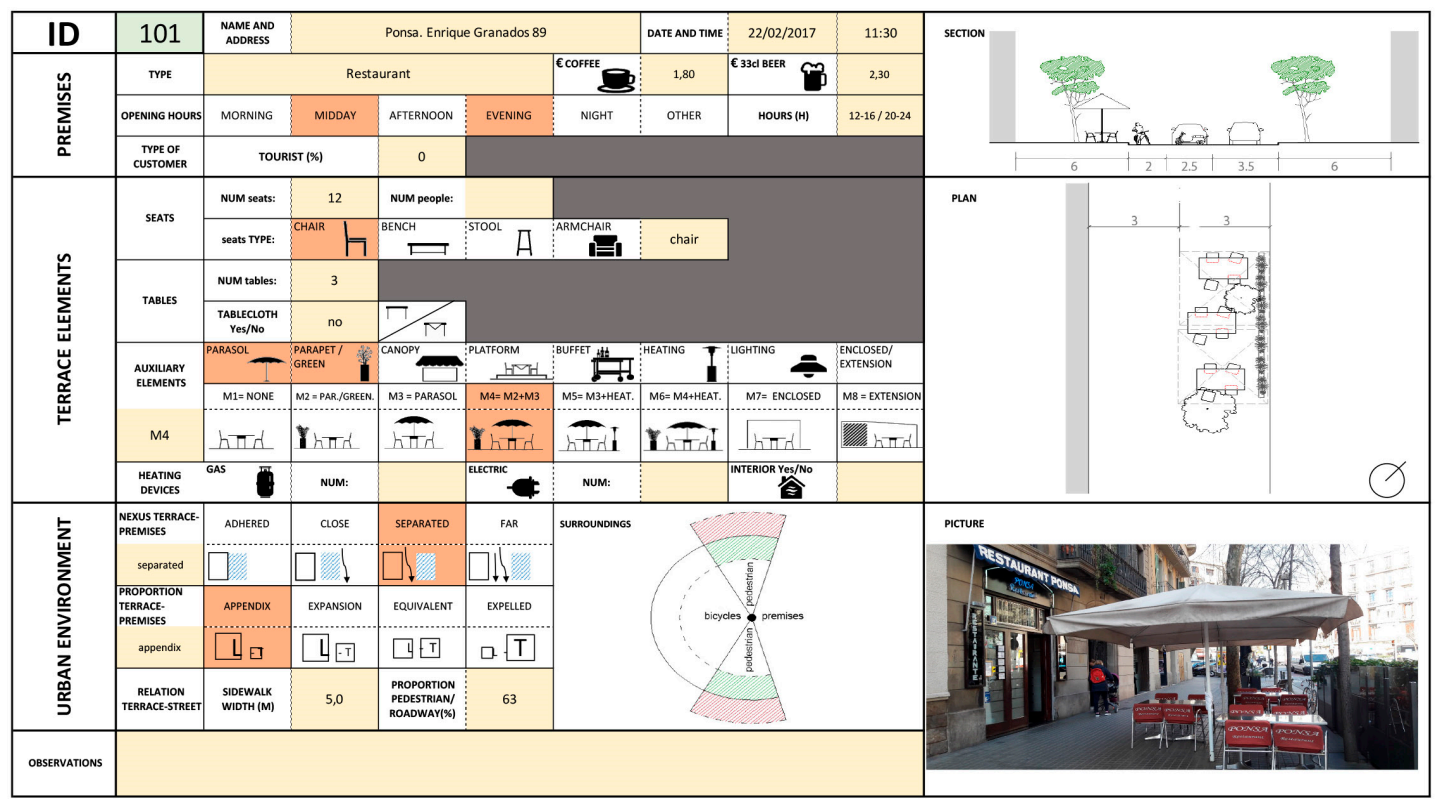

Figure 12. Example of data sheet.

\begin{tabular}{|c|c|c|c|c|c|c|c|c|c|}
\hline ID & 101 & $\begin{array}{l}\text { NAME AND } \\
\text { ADDRESS }\end{array}$ & \multicolumn{4}{|c|}{ Ponsa. Enrique Granados 89} & DATE AND TIME & $22 / 02 / 2017$ & $11: 30$ \\
\hline \multirow{3}{*}{ 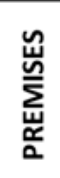 } & TYPE & \multicolumn{4}{|c|}{ Restaurant } & CCOFFEE & 1,80 & E33C BEER & 2,30 \\
\hline & OPENING HOURS & MORNING & MIDDAY & AFTERNOON & EVENING & NIGHT & OTHER & HOURS (H) & $12-16 / 20-24$ \\
\hline & $\begin{array}{l}\text { TYPE OF } \\
\text { CUSTOMER }\end{array}$ & \multicolumn{2}{|c|}{ TOURIST (\%) } & 0 & & & & & \\
\hline
\end{tabular}

Figure 13. Part of the data sheet containing the premises data.

Finally, the urban environment section focuses on three fields: the terrace-premises connection, the terrace-premises proportion and the terrace-street relation (Figure 15). The terrace-premises connection has four possible values: "adhered" when the terrace is in contact with the business; "close" when it is located right next to it, without space for pedestrians to walk in between; "separated" when there is a gap between the terrace and the premises enough for pedestrians to walk by; and "far" when the terrace is separated from the premises by, at least, a car lane.

The terrace-street proportion is also structured in four options: "appendage", "extension", "equivalent" and "dispenser". "appendage" is when the terrace surface is significantly smaller than the indoor part of the food and beverage business. "extension" when the terrace, although still smaller than the business, represents a significant portion of the entire establishment. "equivalent" represents those terraces in which their surface is approximately the same as the surface of the business. Finally, "dispenser" represents those cases when the surface of the terrace is significantly larger than the indoor part of the business.

Finally, the last subsection, the terrace-street relation, considers two fields: the sidewalk width where the terrace is located, and the ratio between sidewalk and total street width (considering sidewalks on both sides of the street). In addition to these variables, this section takes into account the environment concept diagram. This diagram aims to present the influence of the terrace over its immediate environment and the reverse. 


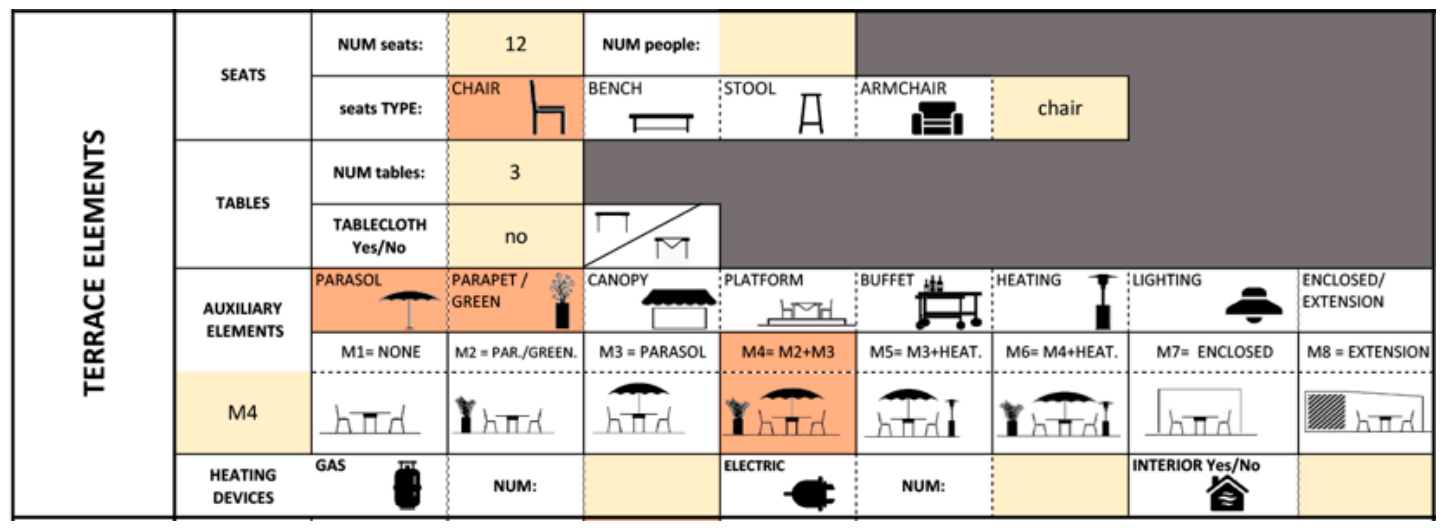

Figure 14. Part of the data sheet containing the terrace elements.

\begin{tabular}{|c|c|c|c|c|c|c|}
\hline \multirow{5}{*}{ 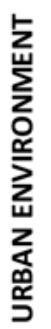 } & \begin{tabular}{|l|} 
NEXUS TERRACE- \\
PREMISES
\end{tabular} & ADHERED & CLOSE & SEPARATED & FAR & \multirow[t]{5}{*}{ SURROUNDINGS } \\
\hline & separated & & & 1 & & \\
\hline & $\begin{array}{l}\text { PROPORTION } \\
\text { TERRACE- } \\
\text { PREMISES }\end{array}$ & APPENDIX & EXPANSION & EQUIVALENT & EXPEULED & \\
\hline & appendix & ᄂ & $5-T$ & $\square=0$ & $\square \cdot \mathrm{T}$ & \\
\hline & $\begin{array}{c}\text { RELATION } \\
\text { TERRACE-STREET }\end{array}$ & $\begin{array}{l}\text { SIDEWALK } \\
\text { WIDTH (M) }\end{array}$ & 5,0 & $\begin{array}{l}\text { PROPORTION } \\
\text { PEDESTRIAN/ } \\
\text { ROADWAY(\%) }\end{array}$ & 63 & \\
\hline
\end{tabular}

Figure 15. Part of the data sheet containing the Urban environment section.

The field work consisted in collecting the data using the previously described spreadsheet in the six mentioned areas and processing it with Geographic Information System (GIS), using ArcMap 10.4 (Esri) as the main software. The data collection was carried out in the winter of 2017, throughout February and March, a period which will be the reference for the below comparisons with other representative values. The sample collected for the present investigation comprises a total of 268 terraces, which are divided as follows:

- Z1_Enrique Granados: 49;

- Z2_Poble Nou: 25;

- Z3_Plaza Reial 44;

- Z4_Mercat Born 50;

- Z5_Av. Gaudí: 50;

- Z6_Parallel: 50.

\section{Results and Discussion}

From a total of 268 studied terraces, 120 (45\%) have heating devices. From these 45\%, 87 terraces have gas cylinder heaters, while 22 have electric heaters and 11 have both.

When calculating the total installed power that these terraces represent $(3100 \mathrm{~kW})$, gas cylinder heaters are responsible for $97 \%(3000 \mathrm{~kW})$, while only the remaining 3\% $(87 \mathrm{~kW})$ is due to the 145 electric heaters. Due to the low percentage of terraces with electric heating devices, the energy analysis presented in the final discussion only considered gas heating values.

These terraces have a total of 4018 seats and occupy a total area of approximately $2878 \mathrm{~m}^{2}$. Using these calculations, the average installed power per square meter can be approximated, resulting in $997 \mathrm{~W} / \mathrm{m}^{2}$ (Table 2). 
Table 2. Calculation of the average installed power per square meter, considering only terraces with gas.

\begin{tabular}{ccccc}
\hline Terraces & Seats & Installed Power $(\mathbf{k W})$ & Area $\left(\mathbf{m}^{\mathbf{2}}\right)$ & $\mathbf{W} / \mathbf{m}^{\mathbf{2}}$ \\
\hline 98 & 4018 & 2868 & 2878 & 997 \\
\hline
\end{tabular}

In order to gain further insight into the use of heating devices in terraces, data retrieved were analyzed regarding two main factors: the installed power per square meter by zone (Table 3) and the differences in heating type in terraces, by zone and by size.

Table 3. Total installed power and installed power per square meter by zone.

\begin{tabular}{ccc}
\hline Zone & Installed Power $\mathbf{( k W )}$ & Installed Power Per $\mathbf{~ m}^{\mathbf{2}} \mathbf{( W / \mathbf { m } ^ { \mathbf { 2 } } )}$ \\
\hline Z1 Enrique Granados & 192 & 1931 \\
Z2 Poblenou & 228 & 1124 \\
Z3 Plaça Reial & 1392 & 822 \\
Z4 Mercat del Born & 672 & 1163 \\
Z5 Avinguda Gaudí & 204 & 1329 \\
Z6 Paral-lel-Blai & 180 & 1195 \\
\hline
\end{tabular}

The following chart (Figure 16) analyzes the dimension of the terraces, estimated by the number of seats and divided by their heating type: gas (red dots), electric (yellow dots), none (blue dots).

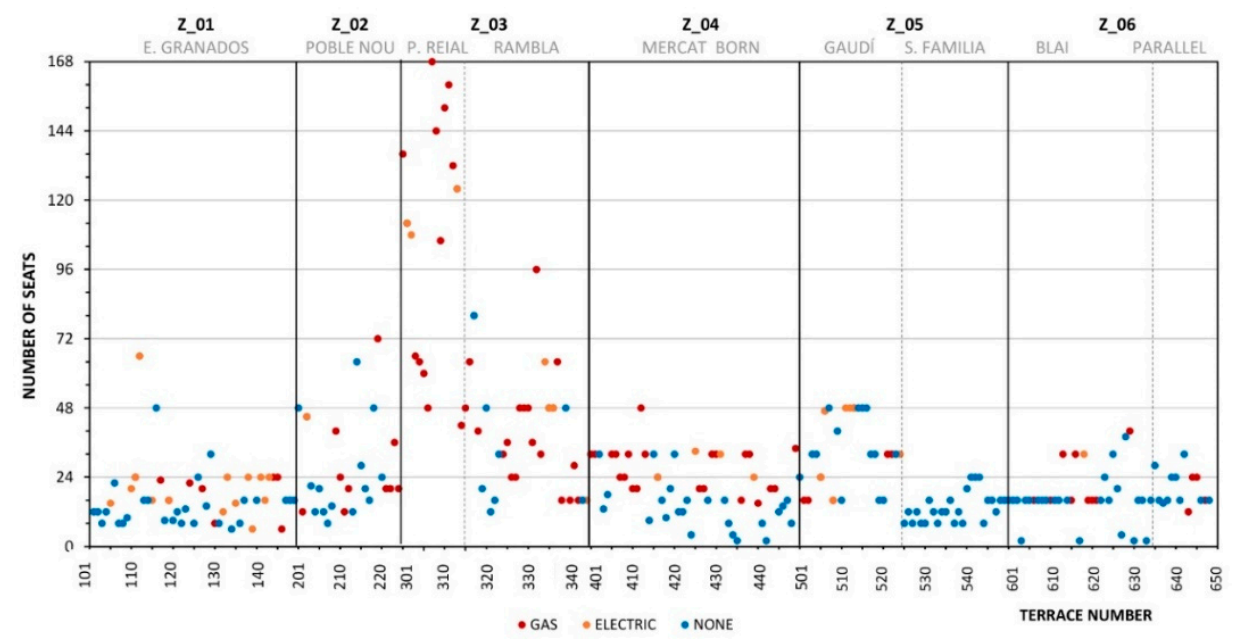

Figure 16. Terraces by number of seats and heating type, organized by zones.

When focusing on the percentage of terraces without heating devices, Avinguda Gaudi and Paral-lel/Blai have a value above 70\%, while zones such as Enrique Granados, Poble Nou and Mercat del Born have approximately 50\% and Plaça Reial under $20 \%$. In all the zones, the percentage of terraces with heating is lower than the percentage of terraces without it, except for the case of Plaça Reial.

It can be observed that Plaça Reial is the area with the greatest percentage of terraces with heating and also the one with the highest total installed power of all the evaluated zones. However, as seen in the previous table, the resulting values of installed power per square meter are the lowest of all the areas. Considering that the terraces in this location are also the largest ones, it can be concluded that the dimension of the terraces greatly influences the installed power per square meter value.

If the same data are re-arranged in descending order by dimension, given in number of seats, other observations can be made (Figure 17). 


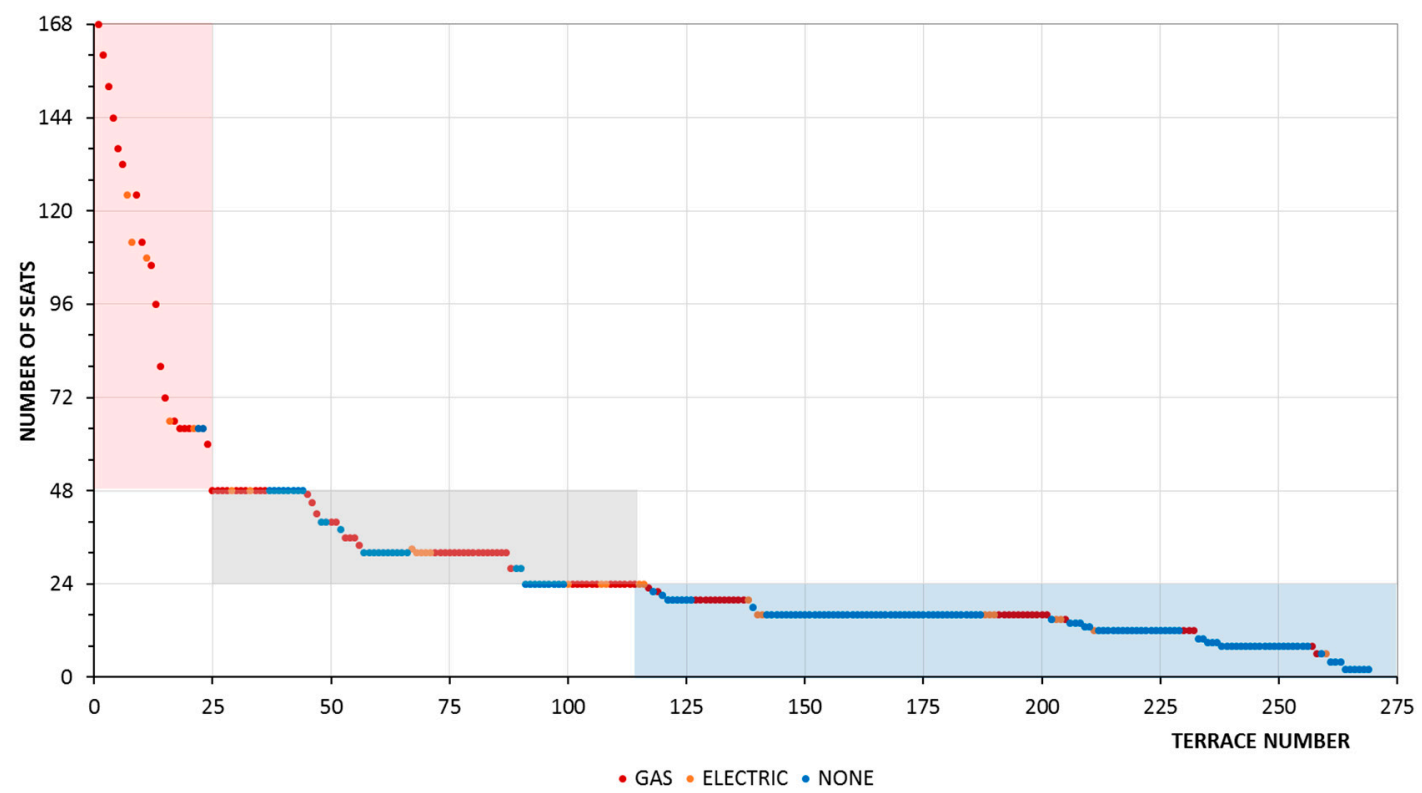

Figure 17. Terraces by number of seats and heating type.

The highest number of terraces without any type of heating device is represented by the terraces with less than 24 seats. Above this limit, a significant number of terraces have heating devices. Furthermore, only two of the terraces with more than 48 seats do not have heating devices. Consequently, three main groups of terraces were identified regarding size that respond to heating criteria, from 0 to 24 seats, from 24 to 48 seats and above 48 seats.

The following table (Table 4 ) indicates the value of installed power per square meter calculated for each of the three main groups (size in square meters calculated with the aforementioned $0.77 \mathrm{~m}^{2} /$ seat value).

Table 4. Installed power per square meter in terraces by size group.

\begin{tabular}{cc}
\hline Seats & Installed Power Per $\mathbf{m}^{\mathbf{2}}\left(\mathbf{W} / \mathbf{m}^{\mathbf{2}}\right)$ \\
\hline Less than 24 seats & $1535 \mathrm{~W} / \mathrm{m}^{2}$ \\
24-48 seats (extremes included) & $1058 \mathrm{~W} / \mathrm{m}^{2}$ \\
Greater than 48 seats & $918 \mathrm{~W} / \mathrm{m}^{2}$ \\
\hline
\end{tabular}

It can be observed that around $90 \%$ of large terraces ( $>48$ seats) have heating devices.

Municipal regulations set a heating load per square meter limit of $0.7 \mathrm{~kW} / \mathrm{m}^{2}$ [26]. The installed power per square meter of large terraces ( $>48$ seats) is close to the regulations. On the other hand, in the case of small terraces ( $<24$ seats) which constitute only $20 \%$ of this group, the installed power per square meter tends to surpass the municipal regulations by approximately twice the limiting value $\left(1.5 \mathrm{~kW} / \mathrm{m}^{2}\right)$.

\section{Energy Considerations}

\subsection{Installed Power and Reference Values}

Heating devices could be classified into two main groups: gas cylinder heaters and electric ones. In order to analyze the installed power of every terrace, nominal power values for these gas and electric heaters were assigned. An average power of $12 \mathrm{~kW}$ was assigned to the gas cylinder heaters and an average power of $0.6 \mathrm{~kW}$ to the electric ones. These values represent the maximum power and were obtained from catalog specifications of most of the available heaters installed in these zones [30-32]. 
In order to obtain a reference baseline to assist in comparing the results obtained regarding power installed in the terraces, five power values are considered and estimated as follows.

(a) The average solar radiation flux $\left(\mathrm{W} / \mathrm{m}^{2}\right)$, referring to a $24 \mathrm{~h}$ period, received by a horizontal surface in Barcelona, with no obstructions, in an average day in March.

The value used was obtained from the EPW climatic file of the DesignBuilder simulation, based on data from the Meteorology Station of El Prat de Llobregat, Barcelona, with a value of $200 \mathrm{~W} / \mathrm{m}^{2}$ as global radiation for the simulated average day of March.

It was cross-referenced with two additional values:

Data from the AEMET Agencia Estatal de Meteorología (Spanish State Meteorology Agency) for the month of March 2015 in Barcelona display a global solar radiation of $4.11 \mathrm{kWh} / \mathrm{m}^{2}$ day, in terms of energy. This represents an average solar radiation flux received in a $24 \mathrm{~h}$ period of $171 \mathrm{~W} / \mathrm{m}^{2}$.

Solar radiation data from Catalonian Meteorology Service (MeteoCAT) given by the Station of El Prat de Llobregat, Barcelona, corresponding to 20 March 2017 give a value of $231 \mathrm{~W} / \mathrm{m}^{2}$.

The power of solar radiation received in a surface can be used to set up a first baseline value. The value of $200 \mathrm{~W} / \mathrm{m}^{2}$ represents the average solar radiation received on a horizontal surface before any transformation process. It should be noted that during the sun hours this value can reach around $800 \mathrm{~W} / \mathrm{m}^{2}$. It represents $1 / 5$ of the installed power $\left(1000 \mathrm{~W} / \mathrm{m}^{2}\right)$ or around $1 / 3.5$ of that recommended by municipal regulations $\left(700 \mathrm{~W} / \mathrm{m}^{2}\right)$. This means that terraces are equipped with heating devices that provide an average of five times the solar heating power, similar to being under peak hour sun radiation without any protection.

(b) The heating load of a mean terrace type, enclosed in a single glazed envelope (Figure 18).

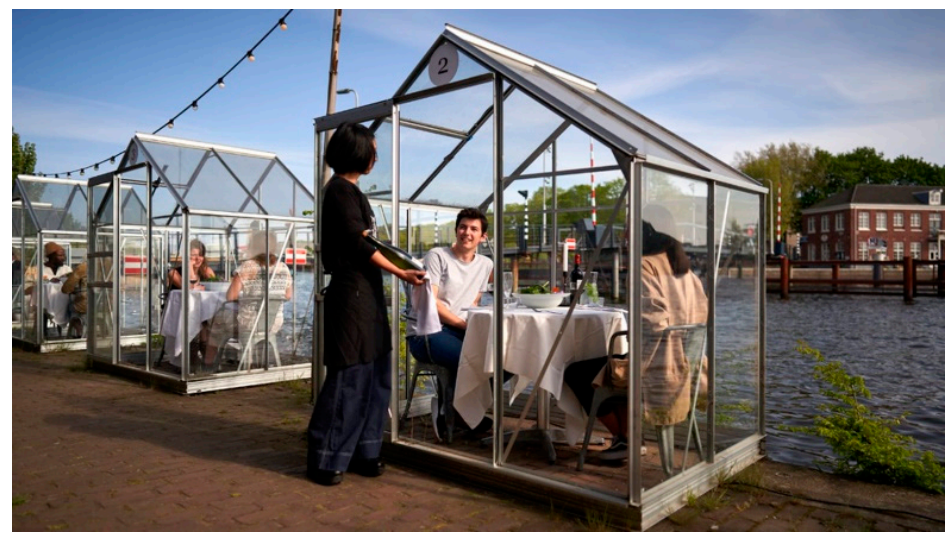

Figure 18. Installation of glazed gazebos at a restaurant's terrace in Amsterdam motivated by the COVID-19 situation. Photography by Willem Velthoven for Mediamatic Amsterdam, Amsterdam, Netherlands, 2020.

The volume of the mean terrace type was calculated based on the average area of terraces with gas heating installed, and a height of $3 \mathrm{~m}$, obtaining a value of $88 \mathrm{~m}^{3}$. The resulting envelope surface considers all the surfaces in contact with the exterior, except with the ground, and resulted in $94.4 \mathrm{~m}^{2}$. The transmittance value estimated for a single glazed curtain wall was $5 \mathrm{~W} /\left(\mathrm{m}^{2} \mathrm{~K}\right)$.

The estimated heating load considers transmission and ventilation losses. The heating load was estimated by the Heating Degree Day (HDD) $\left(20^{\circ}\right)$ method, and the value for Barcelona was used, obtained from the IDAE database [33]. The air renovation load was estimated considering one Air Change per Hour $(\mathrm{ACH})$.

The estimated heating load resulted in $130 \mathrm{~W} / \mathrm{m}^{2}, 65 \%$ of the solar power. 
The installed power at the terraces is around eight times the power necessary to achieve comfort conditions in a glazed enclosure.

(c) The heating load of a mean terrace type, enclosed in an insulated envelope.

The heating load estimated in this case is similar to the previous one but considers a scenario with an insulated envelope. The same value of "mean terrace volume" and the same value of "envelope surface" were taken, but with a transmittance of $0.7 \mathrm{~W} /\left(\mathrm{m}^{2} \mathrm{~K}\right)$. This value is recommended by the Codigo Técnico de la Edificación (CTE), the Spanish regulation for residential buildings [34]. The air renovation load also was estimated considering one Air Change per Hour (ACH). In this case, the result was $24.8 \mathrm{~W} / \mathrm{m}^{2}$.

A more efficient envelope characterized by a transmittance U-value of $0.7 \mathrm{~W} /\left(\mathrm{m}^{2} \mathrm{~K}\right)$ in order to improve the performance yielded only $25 \mathrm{~W} / \mathrm{m}^{2}$. This would reduce the necessary power down to $12.5 \%$ of the solar power and to only a small percentage $(2.5 \%)$ of the installed power in terraces.

Although (b) and (c) values are useful for first rough approximations, they do not reflect real life situations. The exterior surface (S) and the enclosed volume (V) have a relation where the repercussion of the transmittance value is too high. The estimate output of the calculation of heating power per occupied square meter does not reflect usual situations.

This leads us to search for data from living spaces. The first result came from statistical data obtained from a high number of residential buildings used by people in Spain, and a second value was obtained through simulations with DesignBuilder. The aim was to compare the power installed in terraces per square meter with the power needed to heat a square meter of a home. For this reason, two additional values were used for comparison.

(d) The average heating energy consumption in residential buildings in Spain.

The data were extracted from Conama Foundation's report [15], regarding the heating power consumption in residential buildings in Spain, and has a value of $49.3 \mathrm{kWh} / \mathrm{m}^{2}$ annum, which constitutes an average of $5.62 \mathrm{~W} / \mathrm{m}^{2}$. This figure refers to an annual value, including winter and summer months without distinction, which makes it difficult to isolate the focus on the month of March in this study. In any case, it is an interesting value to include in the comparison because it offers an order of magnitude of heating power consumption.

(e) The heating load of a simulated standard residential unit.

Simulations with DesignBuilder were run on typical residential models, similar to the average considered in the aforementioned report [15]. The climate file used was that of Barcelona, with a global radiation value of $200 \mathrm{~W} / \mathrm{m}^{2}$. The values considered regarding the thermal envelope were those recommended by the Spanish regulations [34]. Several comparisons between façades, adiabatic enveloping surfaces and/or those adjacent to the ground were made with respect to their energy exchange. In order to account for unfavorable scenarios, the dwelling models used were those with four or five out of the six enveloping surfaces in contact with the exterior, and only one or 2 adiabatic and/or adjacent to the ground. The results obtained range between 5 and $5.4 \mathrm{~W} / \mathrm{m}^{2}$.

Therefore, the comparison of the average installed power per square meter in terraces in Barcelona with the aforementioned values shows that it is, approximately, 180 times the necessary power to heat a square meter of a residential building and also the average heating energy consumption in residential buildings in Spain.

In order to show these results in a graphical way, two charts are needed. The first one represents a comparison of the reference values mentioned in this section, in $\mathrm{W} / \mathrm{m}^{2}$. The second one aims to properly display the large difference between the reference values, the municipal regulation and the current installed power in terraces. The installed power per square meter for heating in terraces has a high value, often over the value recommended by the municipal regulations (Figure 19b). The regulations of Barcelona limit the heating load by $0.7 \mathrm{~kW} / \mathrm{m}^{2}$. As we have seen, while large terraces often show values per square meter under the regulatory limit, small ones can double the municipal maximum. 


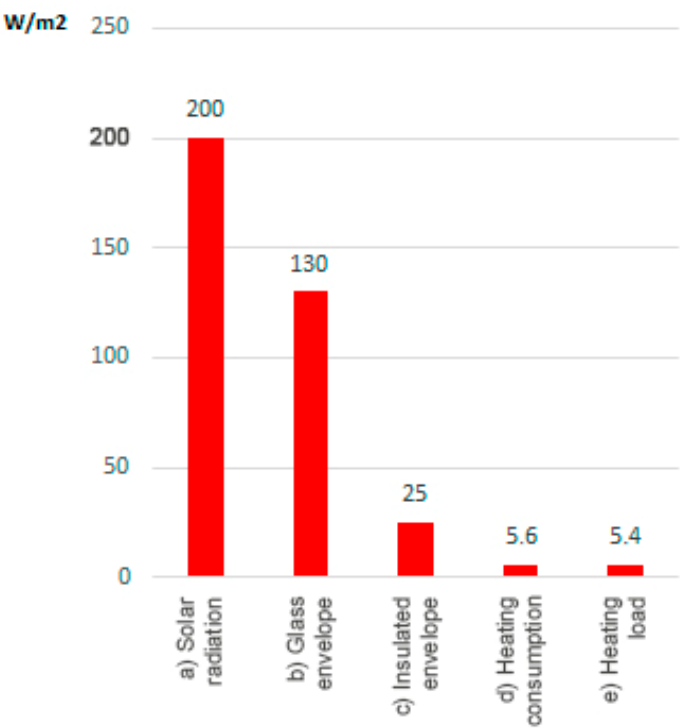

(a)

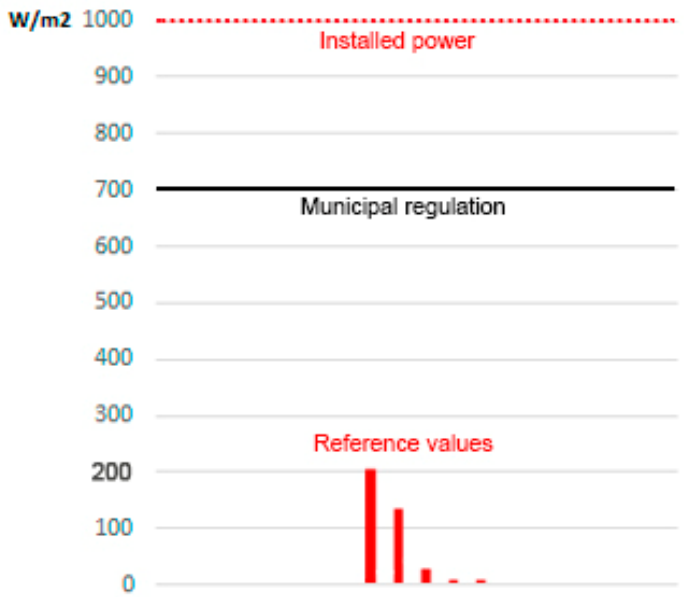

(b)

Figure 19. (a) Power (solar radiation flux and other heating reference values) in $\mathrm{W} / \mathrm{m}^{2}$; (b) reference values vs. installed power in terraces and current municipal regulation.

The fact that regulations set a limit to the installed power per square meter can distort the overall consumption results, as terraces with less installed power in absolute terms might be surpassing the municipal regulations, while terraces with more installed power might not reach the limits.

From the data collected in this survey as well as the samples chosen, it can be stated that the installed power in a terrace is related to the size and number of seats. Urban morphology, microclimatic zone and situation in the city also present certain trends. Terraces in squares, near the sea or in a touristic zone present characteristic features, but a more extended monitoring should be performed to support these points.

If all the available heating devices were turned on, the power consumption could be almost forty times the power needed to keep the interior conditions within regulations (CTE) [34] and 180 times the power needed to maintain the interior conditions of a square meter of an average terrace. Therefore, if the number of terraces continues to increase at the current rate, the impact on power consumption could acquire great significance.

\subsection{Estimated Energy Consumption}

The energy consumed was estimated using different scenarios based on the following variables: opening hours, percentage of installed power used and outdoor air temperature.

Opening hours were set from 8:00 $\mathrm{h}$ to $24: 00 \mathrm{~h}$, based on the regulations of the "Ordenanza de Terrazas de Barcelona" [26]. During weekends and exceptional occasions, terraces can be open two additional hours at night. We did not take into consideration these singular occasions for the calculations, rendering 5840 annual open hours of a total of 8760, with 496 h in March.

The percentage of switched-on heating devices was set either at $100 \%$ or $60 \%$, based on direct observation and surveys to restaurant owners.

Three values $\left(14,16\right.$ and $\left.18{ }^{\circ} \mathrm{C}\right)$ were set based on existing literature on outdoor comfort [35-37]. The number of hours below set temperatures were calculated during the terrace opening hours (Figure 20). 


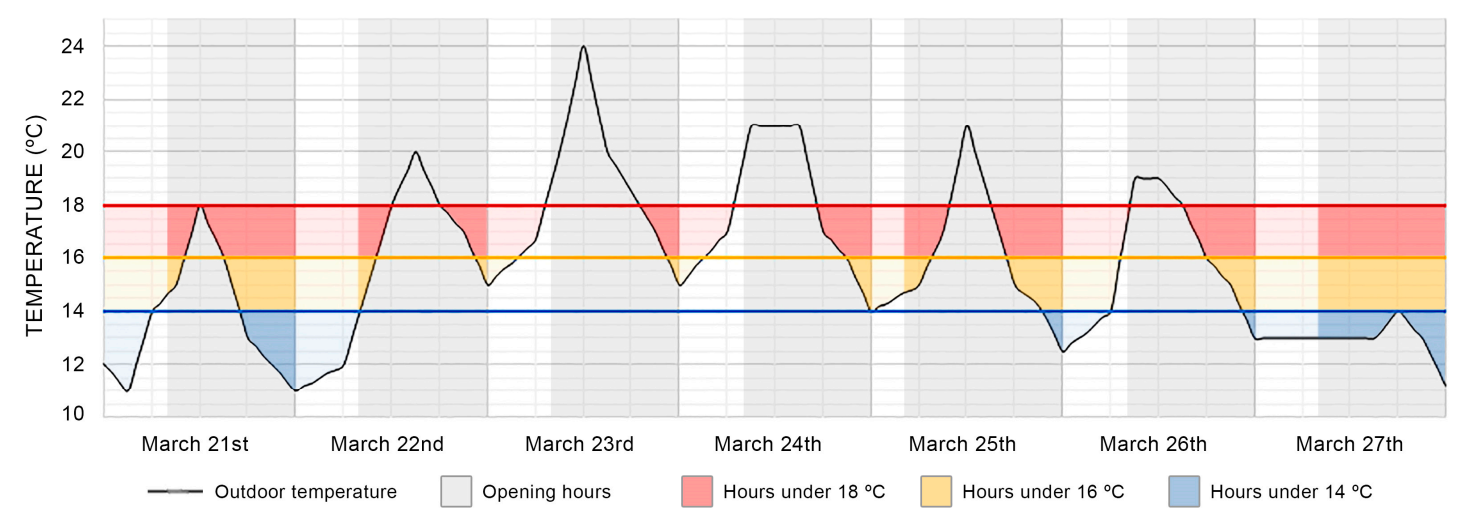

Figure 20. Number of hours below set temperatures during the terrace opening hours in a week.

To define the temperatures in Barcelona, climatic data from the simulation software DesignBuilder were used, also compared with the local meteorological Station Can Bruixa (Table 5).

Table 5. Scenarios and estimated energy consumption for studied terraces.

\begin{tabular}{cccccc}
\hline $\begin{array}{c}\text { Outdoor } \\
\text { Air Temp. }\end{array}$ & $\begin{array}{c}\text { Hours under } \\
\text { Set Temp. } \\
\text { (Annual) }\end{array}$ & $\begin{array}{c}\text { Estimated 100\% } \\
\text { Energy Consumption } \\
\text { (Annual) }\end{array}$ & $\begin{array}{c}\text { Estimated 60\% } \\
\text { Energy Consumption } \\
\text { (Annual) }\end{array}$ & $\begin{array}{c}\text { Hours under Set } \\
\text { Temp. (March) }\end{array}$ & $\begin{array}{c}\text { Estimated 100\% } \\
\text { Energy Consumption } \\
\text { (March) }\end{array}$ \\
\hline$<14^{\circ} \mathrm{C}$ & $2165 \mathrm{~h}$ & $6209 \mathrm{MWh}$ & $3725 \mathrm{MWh}$ & $271 \mathrm{~h}$ & $\begin{array}{c}\text { Estimated 60\% } \\
\text { Energy Consumption } \\
\text { (March) }\end{array}$ \\
$<16{ }^{\circ} \mathrm{C}$ & $2716 \mathrm{~h}$ & $7789 \mathrm{MWh}$ & $4673 \mathrm{MWh}$ & $352 \mathrm{~h}$ & $777 \mathrm{MWh}$ \\
$<18^{\circ} \mathrm{C}$ & $3285 \mathrm{~h}$ & $9421 \mathrm{MWh}$ & $5653 \mathrm{MWh}$ & $421 \mathrm{~h}$ & $1009 \mathrm{MWh}$ \\
\hline
\end{tabular}

The study was conducted on 268 terraces, with $36.5 \%$ having heating devices. The total number of terraces of the municipal census in June 2020 was 5650, not accounting for those exceptionally authorized due to COVID-19 [38].

\section{Conclusions}

This study is centered on terraces of food and beverage businesses located in the public realm, with a particular focus on the energy use of heating devices installed during the winter months. We analyzed a set of case studies that were used as a reference to calculate installed power values for heating devices and, through different scenarios, estimated the potential energy consumed. These values were compared with a set of baselines to give an indication of the importance of considering this outdoor dining from an energy consumption angle.

While residential buildings might be the focus of current energy concerns, this study points out that activities performed outdoors, such as consuming food or drinks in a terrace while socializing, could be the cause for the radical increase in the overall power consumption of an individual's daily activity [39].

In addition, the current COVID-19 pandemic has added more urgency to the study of this practice, as the presence of outdoor dining is dramatically increasing everywhere. The biggest challenge is found in cities where the outdoor climate conditions will require heating devices for a long period of time in the year.

In order to guarantee an overall sustainable trajectory in our ways of living, it is important to anticipate and monitor new practices that could become a challenge to our environmental objectives. Therefore, appropriate regulations are needed in order to ensure that the comfort of the user in terraces is not provided at the expense of unnecessary energy consumption.

This study also aims to highlight how current regulations tend to be limited in their approach. There is a clear difference between regulations that set up a limit value of installed power and regulations that specify features that would guarantee the creation of 
certain environmental conditions. The Codigo Técnico de la Edificación (CTE) [34] is the latter type of regulations, while the Ordenança de terrasses, current municipal regulations on terraces [26], is the former type.

A possible improvement could be basing the regulations on outdoor air temperature instead of only relying on values weighted by square meter [40]. Although the consumption would still be high, turning heaters off in the middle of the day, when the temperature rises, would be a feasible strategy to reduce it. The best option, however, would be to base the entire approach to providing comfort on the environmental conditions at hand and the needs of users, considering using radiant solutions, instead of heating the air of the street. When efforts are directed toward achieving higher sustainability and responsible use of energy, it is important to control spaces that, even though privately owned, are in the public space.

This work aims to open this pathway by showing the significance of the energy consumption in terraces and pointing out following research directions that should be taken in order to achieve a comprehensive understanding of the topic.

With more means and by involving more researchers and institutions, we aim start finding the answers to the questions we have highlighted. Is this extensive use of heating devices sustainable in outdoor terraces in Barcelona? Is the real objective of these devices to improve the thermal conditions of the users, or is there an underlying commercial interest, expressed through a warm visual image projected to the public? If the goal is an improvement of the thermal conditions, would it not be better to use radiant systems that modify the radiant temperature instead of the air temperature? If the main objective is psychological, could we use other visual effects with a similar "warm" image but much lower consumption?

Terraces have been and will continue to be key elements of the public realm, with the capacity of bringing people together or activating the streetscape. More recently, the focus has shifted in allowing social interactions with access to open air and with safety and health measures. In any case, terraces remain an element that can be strategically used to benefit the public realm and urban experience. Therefore, it is important that we study how to improve them at many different levels, from social justice to wellness.

Energy consumption and human comfort should be at the center of focus, and the fact that scarce resources are directed towards "heating the street" should be a major concern.

Author Contributions: The different knowledge and experience of each author have equally contributed to the development and final version of this article. All authors collectively designed the methodology, performed the data collection, analyzed the data and wrote the paper with equal responsibility. All authors have read and agreed to the published version of the manuscript.

Funding: This work was supported by the Spanish Government under the project code BIA2016-77675-R.

Institutional Review Board Statement: Not applicable.

Informed Consent Statement: Meaning is retained.

Data Availability Statement: Not applicable.

Acknowledgments: The support of J. Torres-Quezada and Arch. J. Rotger-Vinent is gratefully acknowledged. Part of the field work was carried out by the students of the master's degree in Advanced Studies at Architecture Barcelona, line of specialization, Architecture, Energy and Environment, 2016-17 edition: Luis Miguel Armendáriz, María Benalcázar, Luana Boiani, Diana Cruz, Javier Fonzo, Joanna Kiedrowska, Aleix Llorach, Lourdes Ruiz, Oriol Roig, Sergio Rojas, Francisco Torres, Catalina Valderrama, Patricia Valdez and Pamela Villegas.

Conflicts of Interest: The authors declare no conflict of interest. 


\section{References}

1. Sahito, N.; Han, H.; Nguyen, T.V.T.; Kim, I.; Hwang, J.; Jameel, A. Examining the Quasi-Public Spaces in Commercial Complexes. Sustainability 2020, 12, 1830. [CrossRef]

2. Rothan, H.A.; Byrareddy, S.N. The epidemiology and pathogenesis of coronavirus disease (COVID-19) outbreak. J. Autoimmun. 2020, 109, 102433. [CrossRef] [PubMed]

3. Serra-Coch, G.; Chastel, C.; Campos-Sánchez, F.-S.; Roura, H.C. Graphical approach to assess urban quality: Mapping walkability based on the TOD-standard. Cities 2018, 76, 58-71. [CrossRef]

4. $\quad$ Espinàs, J.M.; Vilá, E.; Joan, V. Quinze Anys de Cafès de Barcelona, 1959-1974; DOPESA: Barcelona, Spain, 1975.

5. Chen, L.; Wen, Y.; Zhang, L.; Xiang, W.-N. Studies of thermal comfort and space use in an urban park square in cool and cold seasons in Shanghai. Build. Environ. 2015, 94, 644-653. [CrossRef]

6. Zacharias, J.; Stathopoulos, T.; Wu, H. Spatial Behavior in San Francisco's Plazas: The Effects of Microclimate, Other People, and Environmental Design. Environ. Behav. 2004, 36, 638-658. [CrossRef]

7. Santamouris, M.; Cartalis, C.; Synnefa, A.; Kolokotsa, D. On the impact of urban heat island and global warming on the power demand and electricity consumption of buildings-A review. Energy Build. 2015, 98, 119-124. [CrossRef]

8. Haarstad, H. Where are urban energy transitions governed? Conceptualizing the complex governance arrangements for low-carbon mobility in Europe. Cities 2016, 54, 4-10. [CrossRef]

9. Poggi, F.; Firmino, A.; Amado, M. Assessing energy performances: A step toward energy efficiency at the municipal level. Sustain. Cities Soc. 2017, 33, 57-69. [CrossRef]

10. Pereira, I.M.; De Assis, E.S. Urban energy consumption mapping for energy management. Energy Policy 2013, 59, 257-269. [CrossRef]

11. Holden, E.; Norland, I.T. Three Challenges for the Compact City as a Sustainable Urban Form: Household Consumption of Energy and Transport in Eight Residential Areas in the Greater Oslo Region. Urban Stud. 2005, 42, 2145-2166. [CrossRef]

12. Blanco, N. 5.1 Millones de Personas no Pueden Calentar sus Hogares en ESPANA, Diario16. Available online: http:/ /diario16. com/51-millones-de-familias-no-pueden-calentar-sus-hogares-en-espana (accessed on 2 September 2016).

13. Foster, D. Why is one older person dying every seven minutes during the winter? The Guardian. Available online: https: //www.theguardian.com/society/2016/jan/20/older-person-dying-winter-fuel-poverty (accessed on 13 September 2016).

14. Departamento de Planificación y Estudios, Gobierno de España, Secretaria General. Proyecto SECH-SPAHOUSEC, Análisis del Consumo Energético del Sector Residencial en España-Informe Final; IDAE (Instituto para la Diversificación y Ahorro de la Energía): Madrid, Spain, 2011.

15. Cuchí, A.; Arcas-Abella, J.; Pagès-Ramon, A. Estudio de la Distribución del Consumo Energético Residencial Para Calefacción en España. Subdirección General de Urbanismo, Ministerio de Fomento. [Green Building Council España 2017]. 2017. Available online: https://www.fomento.gob.es/NR/rdonlyres/53E31468-1B09-4123-A05B-0FBEB86B858E/149686/201804_Estudio_ distribucion_consumo_energetico_res.pdf (accessed on 30 November 2017).

16. Salvati, A.; Monti, P.; Roura, H.C.; Cecere, C. Climatic performance of urban textures: Analysis tools for a Mediterranean urban context. Energy Build. 2019, 185, 162-179. [CrossRef]

17. Carpino, C.; Bruno, R.; Arcuri, N. Social housing refurbishment for the improvement of city sustainability: Identification of targeted interventions based on a disaggregated cost-optimal approach. Sustain. Cities Soc. 2020, 60, 102223. [CrossRef]

18. Lucchi, E.; Delera, A.C. Enhancing the Historic Public Social Housing through a User-Centered Design-Driven Approach. Buildings 2020, 10, 159. [CrossRef]

19. Pérez, J.; Lázaro, S.; Lumbreras, J.; Rodríguez, E. A methodology for the development of urban energy balances: Ten years of application to the city of Madrid. Cities 2019, 91, 126-136. [CrossRef]

20. Salvati, A.; Coch Roura, H.; Cecere, C. Assessing the urban heat island and its energy impact on residential buildings in Mediterranean climate: Barcelona case study. Energy Build. 2017, 146, 38-54. [CrossRef]

21. Fichera, A.; Inturri, G.; La Greca, P.; Palermo, V. A model for mapping the energy consumption of buildings, transport and outdoor lighting of neighbourhoods. Cities 2016, 55, 49-60. [CrossRef]

22. B.O.E. Jefatura del Estado, Gobierno de España Ley 42/2010, de 30 de Diciembre, Boletín Oficial del Estado n.318. 2010. Available online: https: / / www.boe.es/eli/es/1/2010/12/30/42/con/ (accessed on 30 November 2017).

23. Ajuntament de Barcelona. Se Aprueba Inicialmente la Mejora y Ampliación de Aceras de la Via Laietana. Available online: https://www.barcelona.cat/mobilitat/es/actualidad-y-recursos/noticias/se-aprueba-inicialmente-la-mejora-y-ampliacionde-aceras-en-la-via-laietana_643293 (accessed on 17 April 2018).

24. Ajuntament de Barcelona. La Nueva Rambla, una Transformación al Servicio de las Personas. Available online: https:// ajuntament.barcelona.cat/lesrambles/es / noticia/la-nueva-rambla-una-transformacion-al-servicio-de-las-personas_729668 (accessed on 2 November 2018).

25. García-Almirall, P. Estudi de Caracterització i Avaluació de Terrasses en Espai Públic, Modificació de les Ordenances de Taxes Fiscals de les Terrasses, CPSV (Centre de Política del Sol i Valoracions). 2016. Available online: http://hdl.handle.net/2117/97548 (accessed on 1 March 2017).

26. BOPB. Ordenança de Terrasses, Butlletí Oficial de la Provincia de Barcelona, Barcelona. 2014. Available online: https:// ajuntament.barcelona.cat/eixample/es/ordenanzas-de-terrazas (accessed on 30 September 2020). 
27. Castán, P. Restauradores Plantean Acuerdo Para Acabar la Guerra de las Terrazas, elPeriódico. Available online: http:/ / www.elperiodico.com/es/barcelona/20170712/los-restauradores-plantean-acuerdo-minimos-para-acabar-guerraterrazas-barcelona-6164509 (accessed on 7 July 2017).

28. Cugat, R. Las Claves de la Regulación de las Terrazas en BCN, elPeriódico. 2017. Available online: http:/ /www.elperiodico.com/ es/sociedad/20150716/claves-regulacion-terrazas-bcn-4361228/ (accessed on 15 September 2017).

29. Giannoni, P. Terrazas, en el Espacio Público. Master's Thesis, Polytecnic University of Catalonia, Barcelona, Spain, 2015. Available online: https:/ / etsab.upc.edu/ca/escola/qualitat/vsma-titulacions/acreditacio2018/ex-mbarch/tfm-15-notable-gp. pdf (accessed on 30 September 2017).

30. Home Depot. Patio Heaters [Online]. 2017. Available online: https://buenosybaratos.es/hogar-y-cocina/estufa-de-gas/lamejor-estufa-de-gas-exterior / (accessed on 15 June 2020).

31. Forcali Seta. ¿Cuáles son las Mejores Estufas de Gas Exterior? [Online]. 2017. Available online: https://buenosybaratos.es/hogary-cocina/estufa-de-gas/la-mejor-estufa-de-gas-exterior/ (accessed on 15 June 2020).

32. Media Market. Estufa Eléctrica de Baño Orbegozo BB4000 750W, 1 Barra de Cuarzo [Online]. 2017. Available online: https: / / tiendas.mediamarkt.es/p/estufa-electrica-de-bano-orbegozo-bb-4-1178399 (accessed on 15 June 2020).

33. IDAE (Instituto para la Diversificación y Ahorro de la Energía). Ahorro y Eficiencia Energética en Climatización: Guía Técnica Condiciones Climáticas Exteriores de Proyecto. 2010. Available online: https: / /www.idae.es/tecnologias/eficiencia-energetica/ edificacion/reglamento-de-instalaciones-termicas-de-los-0/ (accessed on 30 September 2017).

34. Código Técnico de la Edificación, CTE. Ley 38/1999 de 5 de Noviembre, de ORDENACIÓN de la Edificación (LOE). Gobierno de España. 2006. Available online: https:/ / www.codigotecnico.org (accessed on 31 December 2019).

35. Nakano, J.; Tanabe, S.-I. Thermal Adaptation and Comfort Zones in Urban Semi-Outdoor Environments. Front. Built Environ. 2020, 6. [CrossRef]

36. American Society of Heating, Refrigerating, and Air-Conditioning Engineers [ASHRAE]. ANSI/ASHRAE Standard 55-2017: Thermal Environmental Conditions for Human Occupancy; American Society: Peachtree Corners, GA, USA, 2017.

37. Nikolopoulou, M.; Lykoudis, S. Thermal comfort in outdoor urban spaces: Analysis across different European countries. Build. Environ. 2006, 41, 1455-1470. [CrossRef]

38. Open Data BCN. Available online: https://opendata-ajuntament.barcelona.cat/data/es/dataset/terrasses-comercos-vigents/ resource/cc7963b4-e3c9-461d-88a3-0f7ba0b0f46f (accessed on 31 December 2020).

39. Karakounos, I.; Dimoudi, A.; Zoras, S. The influence of bioclimatic urban redevelopment on outdoor thermal comfort. Energy Build. 2018, 158, 1266-1274. [CrossRef]

40. Spagnolo, J.; De Dear, R. A field study of thermal comfort in outdoor and semi-outdoor environments in subtropical Sydney Australia. Build. Environ. 2003, 38, 721-738. [CrossRef] 